\title{
Forest soil conservation based on eco-service provision unit method and its value in Anji County, Huzhou, Zhejiang, China
}

\author{
Biao Zhang ${ }^{1} \cdot$ Ji-xi Gao $^{2} \cdot$ Gao-di Xie ${ }^{1} \cdot$ Chun-xia Lu ${ }^{1}$
}

Received: 28 March 2014/Accepted: 30 April 2014/Published online: 29 April 2015

(C) Northeast Forestry University and Springer-Verlag Berlin Heidelberg 2015

\begin{abstract}
We propose an eco-service provision unit method for estimating the benefit and spatial differences of forests in controlling soil erosion. A total of 197 eco-service provision units were grouped on $1424.43 \mathrm{~km}^{2}$ of forest according to differences in vegetation, slope, soil, and rainfall. The amount of soil conservation and its economic value were estimated. The forests in Anji County prevent $4.08 \times 10^{5}$ tons of soil from eroding annually, thereby avoiding $1.36 \times 10^{4}$ tons of nutrient loss (on-site cost) and preventing 149 tons of nutritive elements from entering water systems (off-site cost). From an economic perspective, the soil nutrient conservation in the forests of Anji County generated an annual benefit of 43.37 million RMB (Chinese Currency, 6.20 RMB = US\$1). On average, each hectare of ecological forest contributed up to $436 \mathrm{RMB}$ annually because of soil conservation. Ecological complexes with higher rainfall intensity, such as broadleaf forest and red soil on slope gradients $>25^{\circ}$, contributed the highest soil conservation benefits. This study identified and quantified the dominant contributors and magnitudes of soil conservation provided by forests. This information can benefit decision making regarding differentiated ecological compensation policies.
\end{abstract}

The online version is available at http://www.springerlink.com

Corresponding editor: Chai Ruihai

Biao Zhang

zhangbiao@igsnrr.ac.cn

1 Institute of Geographical Sciences and Natural Resources Research, Chinese Academy of Science, Beijing 100101, China

2 Nanjing Institute of Environmental Sciences, Ministry of Environmental Protection, Nanjing 210042, China
Keywords Soil erosion and conservation - Eco-service provision unit (ESPU) · Rainfall erosivity · Soil erodibility · Universal Soil Loss Equation (USLE)

\section{Introduction}

Soil erosion is a natural process in which the land surface is worn away by water and/or wind. In addition to causing onsite loss of topsoil and reducing land productivity, soil erosion results in off-site environmental effects, such as water pollution and eutrophication (Morgan 1995; He et al. 2003). According to Pimentel et al. (1995), nearly one-third of the world's arable land has been lost through erosion, and land loss continues at a rate of more than 10 million ha per year. Although soil erosion is natural and unstoppable, its rate is variable and is affected by human activities and land management practices. Kuhlman et al. (2010) categorized soil conservation measures into agricultural practices, forestry measures, and anti-erosion techniques used in construction work. For example, conservation agriculture seeks to avoid unsustainable soil losses while maintaining stable yields (Zhao et al. 2007; Li et al. 2011). Other common measures that reduce erosion include no-till farming (Zhou et al. 2005), the Conservation Reserve Program(USA), cover cropping, strip cropping, vegetation barriers, elimination of summer fallow, and installation of conservation devices, such as terraces, waterways, diversion ditches, gabions, and drop structures (Zobeck and Schillinger 2010; Rejani and Yadukumar 2010; Guto et al. 2011). Kuhlman et al. (2010) estimated the costs and benefits of eight soil conservation measures in Europe and found that the on-site benefits of soil protection measures in forests were less than their costs, whereas the off-site benefits were large. Taihu Basin is located in the lower 
reaches of the Yangtze River Basin and is one of the most developed zones in China. Over the past decades, this basin has been undergoing intensive change in land use because of rapid economic growth and urbanization. Meanwhile, the eutrophication and deterioration of water quality in Taihu Lake, Jiangsu, is increasingly worsening. Therefore, increasing attention has been directed toward the input of nutrients from the upper reaches of Taihu Lake and its environmental effects (Xie et al. 2001; Yu et al. 2003; Li et al. 2004a, 2006). Wang et al. (2003) found that the substance migration resulting from soil erosion was the main carrier of non-point nutrients into the lake. Despite rapidly growing awareness about soil erosion in Taihu Lake Basin (Cao et al. 2002; Wang et al. 2003; Zeng et al. 2008), few studies have quantified the cost and benefit of soil conservation provided by forests in reducing soil erosion and nutrient loss, particularly in water catchment areas.

Eco-compensation is a type of institutional arrangement for maintaining the sustainable use of ecosystem services. This approach adjusts the distribution of costs and benefits between different actors and stakeholders primarily through economic measures (Tack Force on Eco-compensation Mechanisms and Policies 2008). Previous studies on ecological compensation policy in China have analyzed the scope, targets, and standards of compensation by estimating the economic benefits of ecosystem services. Nevertheless, most evaluation methods on ecosystem functions or services that apply to homogeneous ecosystems fail to reveal the spatial heterogeneity and the main contributors of ecosystem services (Zhang et al. 2010). Thus, such methods cannot provide a baseline for diverse and differentiated ecological compensation policies. For example, the majority of modern ecological compensation policies in China adopt a single standard (i.e., area) without considering the differences in natural and/or social characteristics (Qin and Kang 2007). We assume that a recognized ecosystem service is jointly generated by numerous eco-service provision units. Some mileage can be gained from estimating the benefits of an individual ecoservice provision unit in an economic sense, and the differentiated ecological compensation standards can be addressed in terms of the potential positive effects of the ecosystem service.

Therefore, this work estimates the economic value of soil conservation service in Anji County, Huzhou, Zhejiang forests and subsequently analyzes the dominant contributors and their magnitudes to propose a highly diverse standard for ecological compensation policy. This goal requires a detailed inventory to objectively describe the characteristics of a forest ecosystem and to conduct field investigations on soil erosion and nutrient content. This paper is organized as follows: "Materials and methods" section provides a background of the study area. Section "Results and discussion" presents the data and evaluation method. The results are discussed in "Suggestions for ecological compensation policy" section. The policy recommendation and conclusion are given in "Conclusion" section and 6, respectively.

\section{Materials and methods}

\section{Study area}

Anji County $\left(30^{\circ} 23^{\prime}\right.$ to $30^{\circ} 53^{\prime} \mathrm{N}, 119^{\circ} 14^{\prime}$ to $\left.119^{\circ} 53^{\prime} \mathrm{E}\right)$ is located northwest of Zhejiang Province, China (Fig. 1). The area administrated by the Anji County government is $1886 \mathrm{~km}^{2}$ and is composed of 15 villages and towns. This county has undulating topography, with elevation ranging from $500 \mathrm{~m}$ to $1000 \mathrm{~m}$. Anji County has a subtropical oceanic climate with annual precipitation of $1400 \mathrm{~mm}$ and mean temperature of $15.6^{\circ} \mathrm{C}$. Xitiaoxi, located in Anji County, is one of the most important tributaries in the upstream of Taihu Lake, as it supplies $27.7 \%$ of the water volume to Taihu Lake. We selected Anji County as the study site on the basis of the following characteristics of the county: (1) its plentiful forest resources are composed of various forest types; (2) it is located in the headwater of Taihu Lake, where ecological services such as soil conservation and nutrient control are vital to water environment security; and (3) the complete utilization of bamboo forest and economic forest causes severe disturbance (Yu et al. 2003).

According to the data of the Forest Resource Survey of 2007, Anji County's forest ecosystem has a total area of 142,443 ha, of which $15.53,17.35$ and $3.57 \%$ is coniferous forest, broadleaved forest, and broadleaved-coniferous mixed forest, respectively. These forest types account for a total area of 51,932 ha. Economic forest and shrub forest dominate 15,987 and 235 ha, covering 11.22 and $0.16 \%$ of the total forest area, respectively. The remaining $52.15 \%$ is devoted to bamboo forest. Figure 1 shows the spatial distribution of forest resources in Anji County.

\section{Methodology and data}

\section{Eco-service provision unit}

The heterogeneity of ecosystem structures and environmental elements results in spatial variability of functions or services (Guo and Gan 2003). A clear recognition of the spatial heterogeneity of ecosystem services and their main contributors is an advantage for policy making regarding ecological compensation. To identify the link between a group of individuals (from a given species makes to an 
Fig. 1 Study area and its forest distribution

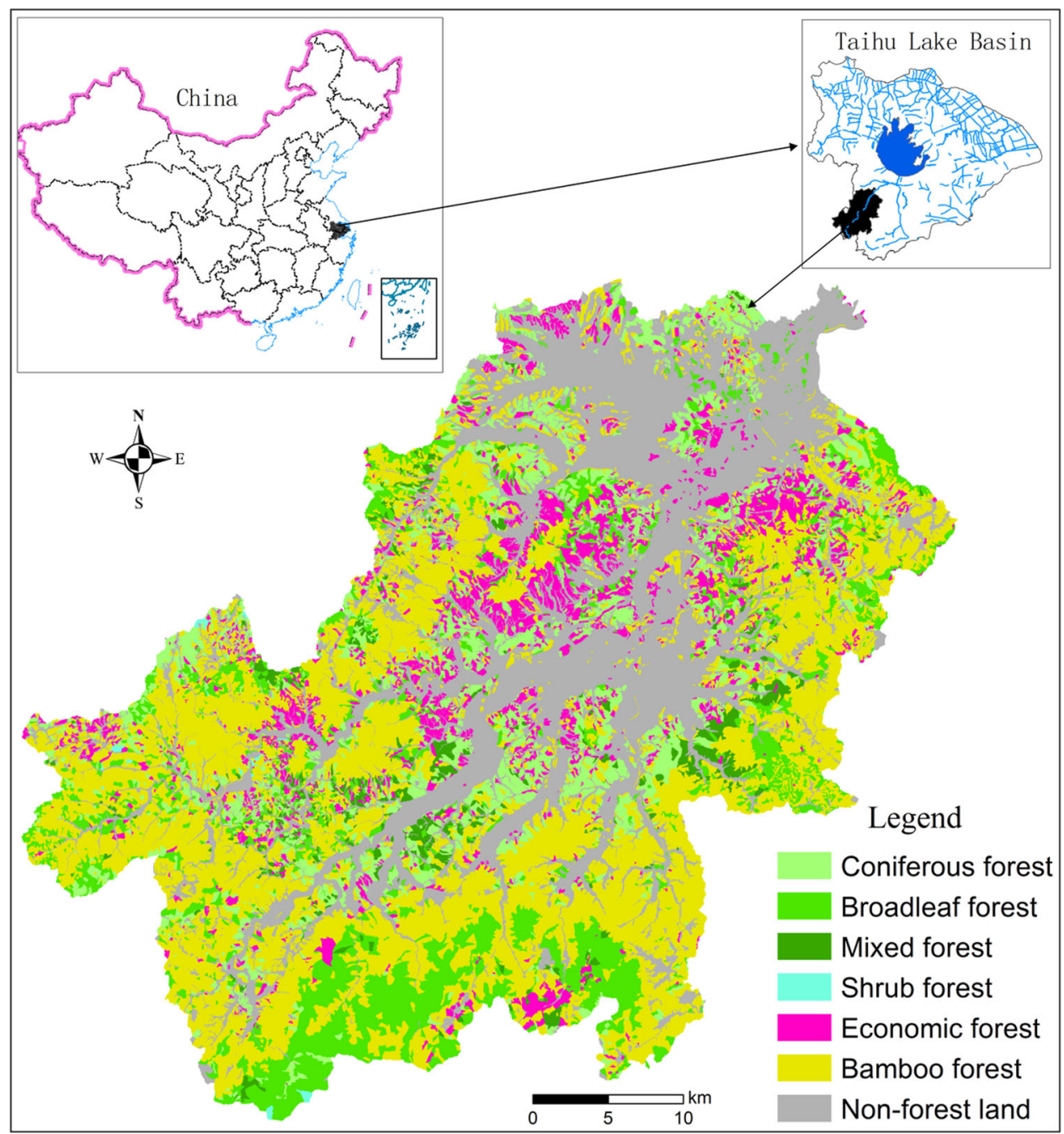

ecosystem service) and the ecosystem service(s) that they provide, Luck et al. (2003) proposed a new population categorization called "service-providing unit (SPU)". SPUs provide, or might provide in the future, a recognized ecosystem services at some temporal or spatial scale. Thus, SPUs should be delineated when assessing the consequences of population change on the provision of ecosystem services. Likewise, we propose an eco-service provision unit (ESPU) as the basic unit of ecosystem service research in this study. ESPU is an ecological complex with the same or similar ecosystem structure and/or environmental attributes (such as climatic, soil, or topography) and can therefore provide the same magnitude of ecosystem services. In the case of soil conservation service, numerous factors such as precipitation, vegetation, soil, and slope jointly influence soil erosion (Zhang et al. 2009). Therefore, a spatial database embodied within a geographic information system (GIS) should be developed as a foundation.
In this study, a spatial database containing information on precipitation, vegetation, soil, and topography was organized using data from the Forest Resource Inventory in Anji County. According to the monthly rainfall data, the rainfall erosivity in Anji County was calculated by using a modified Fournier's index model (Renard and Freimund 1994) and was divided into five classes: higher ( $\left.<120 \mathrm{MJ} \mathrm{mm} \mathrm{hm}{ }^{-2} \mathrm{~h}^{-1} \mathrm{a}^{-1}\right)$, high (121 MJ mm hm ${ }^{-2} \mathrm{~h}^{-1} \mathrm{a}^{-1}-130 \mathrm{MJ} \mathrm{mm} \mathrm{hm}^{-2} \mathrm{~h}^{-1} \mathrm{a}^{-1}$ ), middle (131 MJ mm hm ${ }^{-2} \mathrm{~h}^{-1} \mathrm{a}^{-1}-140 \mathrm{MJ} \mathrm{mm} \mathrm{hm}^{-2} \mathrm{~h}^{-1} \mathrm{a}^{-1}$ ), low (141 MJ mm hm ${ }^{-2} \mathrm{~h}^{-1} \mathrm{a}^{-1}-150 \mathrm{MJ} \mathrm{mm} \mathrm{hm}^{-2} \mathrm{~h}^{-1} \mathrm{a}^{-1}$ ), and lower ( $\left.>150 \mathrm{MJ} \mathrm{mm} \mathrm{hm}^{-2} \mathrm{~h}^{-1} \mathrm{a}^{-1}\right)$. We considered six forest types, namely, conifer, broadleaf, conifer and broadleaf mixed, bamboo, shrub, and economic forest. Soils were of five types: red, yellow, purple, rice, and lime soil. We assigned four slope gradient categories as: less than $5^{\circ}, 5^{\circ}$ to $15^{\circ}, 15^{\circ}$ to $25^{\circ}$, and more than $25^{\circ}$. In theory, the entire county could be grouped into 600 rainfall-vegetation-soil-slope complexes $(5 \times 6 \times 5 \times 4)$; however, according to the spatial database of forest resources, only 197 complexes actually existed. 


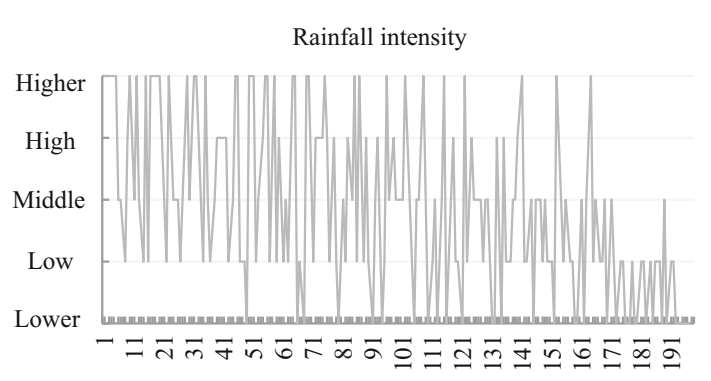

ESPU

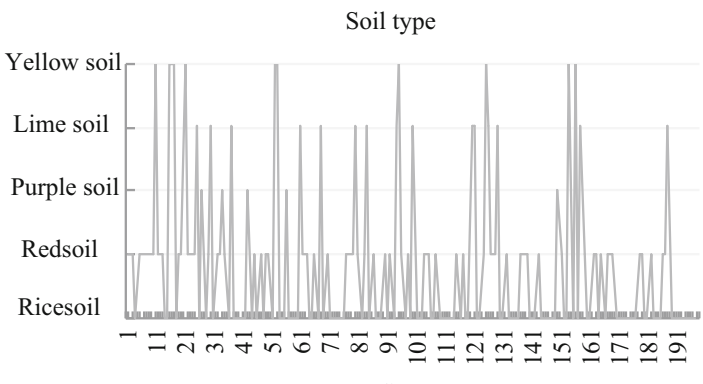

ESPU

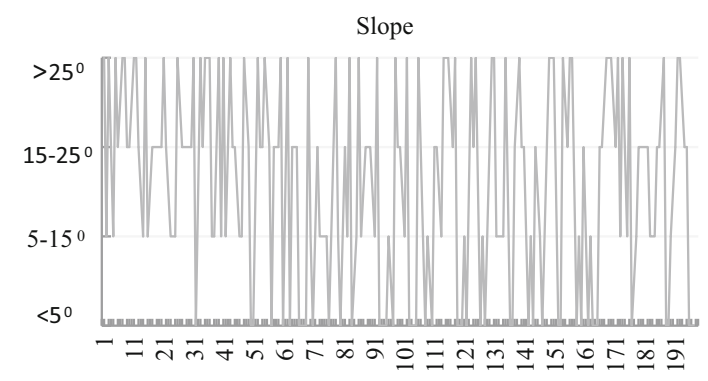

ESPU

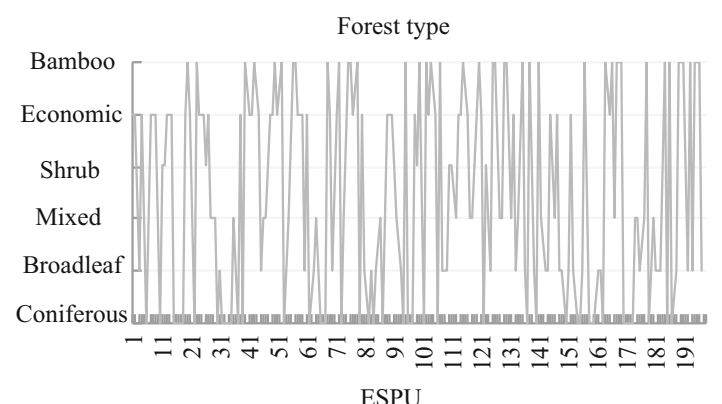

ESPU

Fig. 2 Information on the precipitation, vegetation, soil, and topography of each ESPU

Figure 2 illustrates the information on precipitation, vegetation, soil, and topography of each ESPU. We focused primarily on the environmental benefits of soil conservation provided by the 197 ESPUs.

\section{Amount of soil conservation}

We assumed that the amount of soil conservation can be regarded as the difference between soil erosion quantities arising from forested versus non-forest land in Anji County. Although recent studies have proposed numerous models and methods for predicting the amount of soil erosion (Fu and Liu 2002; Liu et al. 2011), such as Universal Soil Loss Equation (USLE) (Wischmeier and Smith 1978) or revised USLE model (Renard et al. 1997), the actual magnitude of soil erosion remains difficult to quantify. Therefore, we assumed that the modulus of soil erosion can be estimated on the basis of various influencing factors such as climate (rainfall, wind, etc.), soil character (soil erodibility of a specific soil type), topography (slope and length of the field), and land utilization (crop management and erosion control practices) (Seckler 1987). We choose three influencing factors (i.e., rainfall erosivity, soil erodibility, and slope angle) of soil erosion and the field survey results derived from empirical studies to calculate the amount of soil erosion in each ESPU. Rainfall intensity was graded into five categories to represent the rainfall erosivity of each ESPU. We assumed slope to be positively correlated with erosion volume and classified slopes into four levels in accordance with the data from site surveys (Guo et al. 2001). Soil erodibility, which is independent of other factors associated with erosion, such as slope angle, rainfall intensity, or crop management (McIntosh and Laffan 2005), can be assessed by using a combination of laboratory measurements on soil horizons and field descriptions of soil profiles. On the basis of a broad correlation between soil erodibility and soil classification (Grant et al. 1995; Laffan et al. 2003), the soil erodibility of each ESPU was approximately identified by individual soil type with published soil descriptions (Zhang and Han 2000; $\mathrm{Bu}$ et al. 2002). Table 1 shows the relative coefficients of rainfall erosivity, slope angle, and soil erodibility in Anji County.

The soil erosion modulus for each forest type was compiled from a wide variety of publications of site surveys (Table 2). Thus, the overall amount of soil conservation in Anji County forests was estimated using the following formula:

$E S=\sum_{i=1}^{197} \alpha_{i} \times \beta_{i} \times \gamma_{i} \times\left(S_{N o n}-S_{i}\right) \times A_{i}$

where ES is the total amount of soil conservation (ton/yr); $S_{i}$ and $S_{N o n}$ are moduli of soil erosion of different forest types and non-forest land (ton $/ \mathrm{km}^{2}$ ), respectively; $A_{i}$ represents the area of an individual ESPU (ha); and the $i$ subscript indicates the relevant ESPUs. 
Table 1 Adjustment coefficients of soil erodibility $(\alpha)$, rainfall erosivity $(\beta)$, and slope angle $(\gamma)$

\begin{tabular}{llllll}
\hline Soil type & Soil erodibility $(\alpha)$ & Rainfall intensity & Rainfall erosivity $(\beta)$ & Slope & Slope gradient $(\gamma)$ \\
\hline Rice & 1 & Higher & 1 & $<5^{\circ}$ & 0.1 \\
Red & 0.74 & High & 0.8 & Between $5^{\circ}$ and $15^{\circ}$ & 0.33 \\
Purple & 0.64 & Middle & 0.6 & Between $15^{\circ}$ and $25^{\circ}$ & 0.54 \\
Lime & 0.47 & Low & 0.4 & $>25^{\circ}$ & 1 \\
Yellow & 0.20 & Lower & 0.2 & & \\
\hline
\end{tabular}

$\alpha$ roughly identified by corresponding soil type in publications (Zhang and Han 2000; Bu et al. 2002)

$\beta$ graded into five categories based on rainfall intensity

$\gamma$ classified from the site survey data (Guo et al. 2001)

Table 2 Soil erosion moduli of different forest types in Anji County

\begin{tabular}{llllllll}
\hline Forest type & Coniferous $^{\mathrm{a}}$ & Broadleaf $^{\mathrm{a}}$ & Mixed $^{\mathrm{b}}$ & Bamboo $^{\mathrm{a}}$ & Economic $^{\mathrm{c}}$ & Shrub $^{\mathrm{d}}$ & Non-forest $^{\mathrm{c}}$ \\
\hline Erosion modulus(ton $/ \mathrm{km}^{2}$ year) & 352.15 & 294.5 & 186.6 & 722.78 & 1469.13 & 200 & 1681.2 \\
\hline
\end{tabular}

\footnotetext{
${ }^{a}$ Kong et al. (2009)

b Zeng et al. (2008)

c Wang et al. (2003)

d Wang et al. (2010)
}

Table 3 Nutrient contents of different types of forestland in Anji County

\begin{tabular}{lcccrrr}
\hline Nutrient content $(\mathrm{mg} / \mathrm{g})$ & Coniferous & Broadleaf & Mixed & Bamboo & Economic & Shrub \\
\hline TN & 0.617 & 1.176 & 0.964 & 0.859 & 0.838 & 1.355 \\
TP & 0.267 & 0.534 & 0.416 & 0.361 & 0.325 & 0.388 \\
TK & 10.204 & 17.386 & 11.202 & 9.212 & 13.167 & 11.326 \\
OM & 14.643 & 21.779 & 17.485 & 21.208 & 15.004 & 26.986 \\
\hline
\end{tabular}

Source Dong et al. (2011), Zhang et al. (2011)

\section{Amount of nutrient control}

The quantifiable effects of soil erosion are frequently divided along two axes: on-site and off-site effects. Soil erosion causes on-site shortages of basic plant nutrients, such as nitrogen, phosphorus, and potassium, and organic matter, which are essential for crop production (Pimentel et al. 1995). The amount of on-site nutrient loss prevented by forests can be estimated from the amount of soil conservation and the content of relevant nutrients. Thus, we needed data on soil nutrients for different points in time; such data exist only for specific locations and cannot be generalized. In a recent study, we investigated the soil nutrients of a forest near Xitiaoxi River in the upper reaches of Taihu Basin (Zhang et al. 2011). We selected 34 typical plots of bamboo forest, economic forest, pure forest, and mix forest within $1 \mathrm{~km}$ of Xitiaoxi River and tested the contents of effective phosphorus, hydrolysis nitrogen, total nitrogen (TN), and total phosphorus (TP). By studying more than 30 soil properties, such as soil physical and chemical properties for different forest soils in the Anji mountain region, Jiang et al. (2004) quantified variation in these properties by soil depth in forest soil (Table 3 ). We used this information to calculate the potential amount of on-site nutrient control for TN, TP, total potassium (TK), and organic matter (OM) by using the following formula:

$N_{i j}=\sum_{\substack{i=1 \\ j=1}}^{197} \beta_{i j} \times S_{i j}$

where $N_{i j}$ represents the total amount of $j$-th nutrient fixation attributed to soil conservation (ton/year), $\beta_{i j}$ is the $j$-th soil nutrient content of different types of forest land (mg/g), and the $j$ subscript indicates the nutrient types (TN, TP, TK, and OM).

In environmental science, nitrogen and phosphorus are the main non-point source pollutants of surface water and groundwater. The removal of excess nitrogen and phosphorus from soil through erosion may result in environmental problems, such as agricultural non-point 
Table 4 Loss rates and pollutant degradation coefficients of TN and TP

\begin{tabular}{lll}
\hline Pollutant & Lost rate $(\lambda)^{\mathrm{a}}$ & Pollutant degradation coefficient $(\eta)^{\mathrm{b}}$ \\
\hline TN & 0.9 & 0.3539 \\
TP & 0.9 & 0.2148 \\
\hline
\end{tabular}

${ }^{a}$ Cheng et al. (2006)

b $\mathrm{Li}$ et al. (2004b)

source pollution and water quality degradation in both freshwater and marine ecosystems (Page et al. 2005; Gassman et al. 2006). The loss rate, which is an important parameter for describing the process of pollutant entrance into a water body, expresses the ratio of pollutants entering the river through watershed concentration to the accumulated pollutant load coming from the basin slope (Cheng et al. 2006). Meanwhile, the degradation coefficient indicates the fraction of pollution stock that is degraded during a period because of the self-purification capacity of the water body. If no soil conservation occurs, the amount of $\mathrm{TN}$ and TP that would run downstream can be predicted by using the appropriate loss rate and degradation coefficient. Therefore, the potential amount of off-site nutrient fixation can be described by the following equation:

$M_{i}=\sum_{i=1}^{197} N_{i} \times \lambda \times(1-\eta)$

where $M_{i}$ represents the total amount of TN or TP prevented from entering the river because of soil conservation (ton/year), is the loss rate of the pollutant, and $\eta$ is the pollutant degradation coefficient (Table 4).

\section{Economic value of soil conservation}

The costs of soil erosion often combine on-site and off-site effects. The major on-site costs of erosion by water are those expended to replace lost soil nutrients. For example, in the United States, an estimated $4 \times 10^{9}$ tons of soil and $130 \times 10^{9}$ tons of water are lost from $160 \times 10^{9}$ ha of cropland each year, and this values translates into an onsite economic loss of over $\$ 20$ billion for nutrient replacement (Pimentel et al. 1995). Chemical fertilizers can compensate the loss of soil nutrients. Thus, the on-site benefit of nutrient fixation attributed to soil conservation can be estimated by the replacement cost method. Soil erosion not only damages the immediate agricultural area where it occurs but also negatively affects the downstream environment. The most serious off-site damages are caused by soil particles entering the water systems. Transfer pricing is generally considered a relatively simple method for moving goods and services between entities. Several different methods can be used to determine
Table 5 Nutrient contents and prices of different types of fertilizers

\begin{tabular}{lcl}
\hline Fertilizer types & Content $\left(\rho_{j}\right)(\%)$ & Price (RMB/ton) \\
\hline DAP (diammonium phosphate) & $14(\mathrm{TN})$ & 2400 \\
DAP (diammonium phosphate) & $15(\mathrm{TP})$ & 2400 \\
Potassium chloride & $50(\mathrm{TK})$ & 2200 \\
Organic matter & $100(\mathrm{OM})$ & 320 \\
\hline
\end{tabular}

Source State Forestry Administration of China (2008)

transfer prices (Antic and Jablanovic 2000). Basing on the regional compensation standards of environmental resource in Jiangsu Province, China, we determined the transfer price of ecological service on controlling moved pollutants in Taihu Lake Basin. We estimated the total economic value of soil conservation using the following formula:

$$
V_{i}=\sum_{\substack{i=1 \\ j=1}}^{197}\left(N_{i j} \times P_{1} / \rho_{j}+M_{i} \times P_{2}\right)
$$

where $V_{i}$ represents the economic value of soil conservation (RMB/year); $P_{i}$ and $P_{2}$ are the prices of relevant fertilizer and regional compensation for pollutants (RMB/ton), respectively; and $\rho_{j}$ is the nutrient content of different types of fertilizers (\%), as shown in Table 5. However, we note that $V_{i}$ is not the total soil conservation benefit but is rather the total of what can be estimated from the available data.

\section{Data}

This work aimed to quantify the positive effect of forests in mitigating soil erosion and maintaining soil nutrients and to convert these effects into monetary terms. A significant amount of data was used in the estimation process. Most of the data were obtained from Category II of the Anji County forest resource inventory, which was conducted in 2007 by Anji County Forestry Bureau and Zhejiang Forest Resource Monitoring Center by applying 3S technologies (GIS, Remote Sensing and Global Position System) and field investigation. We obtained data for 21,082 forest subplots, ${ }^{1}$ of which 20,069 were represented by forest, 726 were other forest (canopy density $<0.2$ ), and the remainder was devoted to non-forest. This study focused on the 20,069 forest subplots. The spatial location (latitude and longitude), forest type, tree species, slope angle, and soil type of individual subplots were compiled and stored in a forest

\footnotetext{
1 The basic unit of the survey data and management of forest resources, divided on the basis of the differences of land right, land type, forest category, and so on.
} 


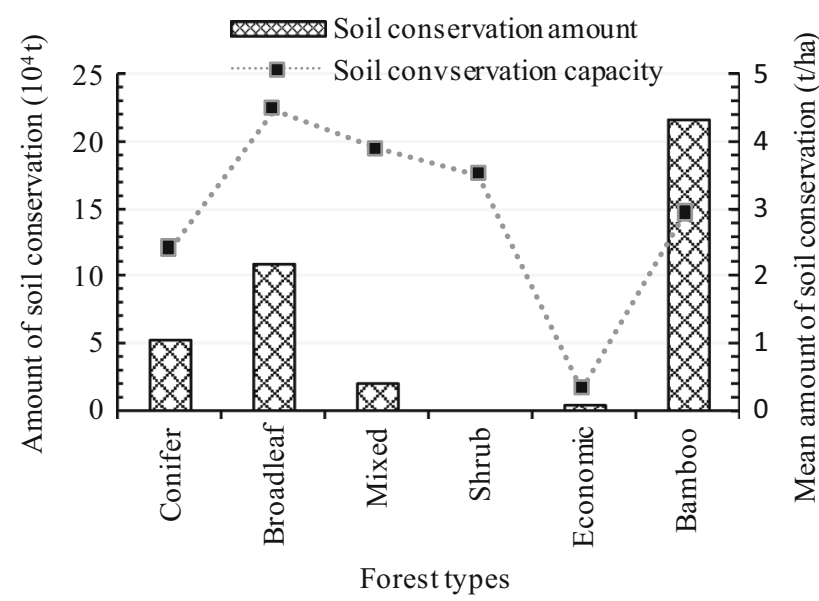

Fig. 3 Amount and capacity of soil conservation in various forest types

resource inventory database on a Web-based GIS managed by the Anji County Forestry Bureau. Abundant precipitation and temperature data from 1975 to 2009 were obtained from Anji County Hydrological Bureau, thus facilitating the assessment of rainfall erosivity. In addition, we consulted numerous case studies on soil erosion and nutrient content in Anji County.

\section{Results and discussion}

\section{Amount of soil conservation}

In general, vegetation can significantly reduce soil erosion. Thus, the soil conservation service of forest ecosystems often attracts significant attention. We calculated that in comparison with non-forest, the 142,443 ha of forest in Anji County could prevent $4.08 \times 10^{5}$ tons of soil from eroding annually. However, large differences were observed in the soil conservation between different forest types. Bamboo forest could reduce $2.18 \times 10^{5}$ tons of soil erosion, thus providing the highest percentage of soil conservation $(53 \%)$. Broadleaf forest prevented $1.11 \times 10^{5}$ tons of soil erosion, comprising $27 \%$ of soil conserved. Conifer forest, conifer and broadleaf mixed forest, and economic forest prevented $5.34 \times 10^{4}, 1.99 \times 10^{4}$, and $5 \times 10^{3}$ tons of soil erosion, comprising 13, 4.9 and $1.2 \%$ of soil conserved, respectively. Shrub forest conserved only 800 tons of soil and thus made the lowest contribution $(0.19 \%)$. The variation in soil conservation was mainly related to forest areas. Figure 3 presents the amounts of soil conservation provided by the different types of forest in Anji County.

Soil conservation capacity per hectare of forest did not follow the same rank order because it is unrelated to forest area. Broadleaf forest had the highest capacity for soil conservation (4.49 ton/ha). Per hectare conifer and broadleaf mixed forest could conserve 3.9 tons of soil, and the soil conservation capacities of shrub, bamboo, and conifer forest were 3.51, 2.93 and 2.41 ton/ha, respectively. Economic forest had the lowest capacity of soil conservation (0.5 ton/ha). The average capacity for soil conservation was $2.86 \mathrm{ton} / \mathrm{ha}$, which coincides with the field survey result in Beijing forests ( 3 ton/ha) (Feng et al. 1998; Yu and Wang 1999). However, it is far less than 1454 ton/ha in the Lancang River Basin (Mekong River), which was calculated using USLE (Chen et al. 2012). Although theoretically all forest types can reduce soil erosion, in reality, the amount of soil conservation is largely dependent on the erosion risk of the study area. For example, the actual function of soil conservation provided by forests may be restricted by low erosion risk (such as flat ground); However, soil conservation can also be effective in the areas with high erosion risk (Zhang et al. 2009). In this study, the erosion risk of each ESPU was determined on the basis of rainfall erosivity, soil erodibility, and slope angle. Eco-service provision unit method generates a highly reliable result for the actual amount of soil conservation.

\section{Amount of nutrient control}

The on-site cost of soil erosion is the shortage of nutrients that are essential for crop production. However, the soil conservation service of forest ecosystems can avoid related nutrients loss. In Anji County, the widely distributed bamboo forest, economic forest, and farmlands are often repeatedly fertilized each year ( $\mathrm{Yu}$ et al. 2003). Thus, the maintenance of soil nutrients is of great importance for the sustainable development of the local economy. The forests in Anji County could annually prevent 277 tons of TN, 120 tons of TP, and 3532 tons of TK from eroding, and 5693 tons of OM (organic matter) could be protected through soil conservation. Therefore, the total amount of soil nutrients protected by Anji County's forest was $1.36 \times 10^{4}$ tons, and the mean capacity for soil nutrient fixation was $95.48 \mathrm{~kg} / \mathrm{ha}$. In addition to substantial on-site losses of nutrients, soil erosion negatively affects the surrounding environment, such as roadway, sewer, and basement siltation, drainage disruption, undermining of foundations and pavements, gullying of roads, earth dam failures, eutrophication of waterways, siltation of harbors and channels, loss of reservoir storage, loss of wildlife habitat and disruption of stream ecology, flooding, damage to public health, and increased water treatment costs (Pimentel et al. 1995). The eutrophication and deterioration of water quality in Taihu Lake is worsening, and the substance migration resulting from soil erosion is the main carrier of non-point nutrients into the lake (Wang et al. 
2003). Results of nutrient fixation assessment showed that the forests of Anji County, which are located upstream of Taihu Lake, could annually prevent 118 tons of TN and 30.68 tons of TP from entering water systems.

\section{Economic value of soil nutrient conservation}

In contrast to the cost of soil conservation efforts, environmental benefits of decreasing soil erosion are difficult to measure (Hansen and Ribaudo 2008). This study evaluated the economic value of soil conservation on the basis of the on-site and off-site costs of soil erosion. The total economic value of Anji County forests for soil conservation was 43.37 million RMB (Chinese yuan) per year. The per hectare soil conservation value of ecological forest (including conifer, broadleaf, mixed, and shrub forest) was $436 \mathrm{RMB}$. Bamboo forest made the highest contribution at approximately 20 million RMB, accounting for $46 \%$ of the total value. The next was broadleaf forest, which contributed approximately 16 million RMB. Conifer and mixed forests made minor contributions to the total value (43.7 thousand and 20.9 thousand RMB, respectively). The economic benefits of soil conservation provided by economic forest and shrub forest were only 5.7 thousand and 1 thousand RMB, respectively. The economic benefits of six types of forest were in proportion to their areas. Significant variances were observed in the relative economic contributions of different types of forest in Anji County. The highest contributor was broadleaf forest at $655 \mathrm{RMB} / \mathrm{ha}$. The economic benefits of soil conservation per unit area of mixed and shrub forests ranged from 410 to $430 \mathrm{RMB} / \mathrm{ha}$. Bamboo and conifer forest contributed 270 and $198 \mathrm{RMB} / \mathrm{ha}$, respectively. Economic forest made a minor economic contribution of $36 \mathrm{RMB} / \mathrm{ha}$. The total and average values of soil conservation in different types of forest are shown in Fig. 4.

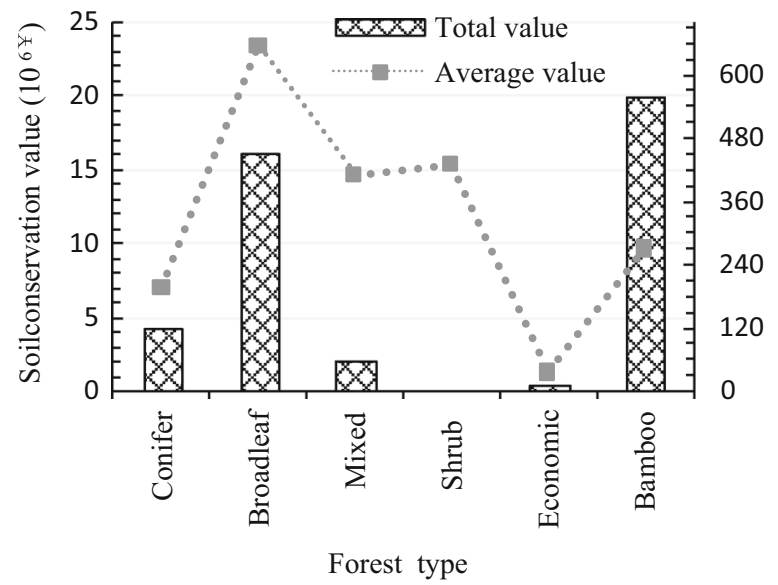

Fig. 4 Soil conservation value of different forest types

\section{Economic value of each ESPU}

Specific knowledge of the economic benefits of per hectare forest in different regions can help in policy design for ecocompensation. Figure 5 shows the total economic value of each ESPU and its average value per hectare. The highest soil conservation benefit was provided by broadleaf forest on slopes of $>25^{\circ}$ with high rainfall intensity and red soil. Broadleaf forest contributed an estimated 6.58 million RMB annually through soil conservation service, and all forest categories combined provided $1498 \mathrm{RMB} / \mathrm{ha}$. The next was bamboo forest with similar slope, rainfall, and soil parameters, which generated an estimated 4.66 million RMB in soil conservation value. Table 6 lists the information on the precipitation, vegetation, soil, and topography of the 11 ESPUs, the cumulative proportion of total economic value of which reached $70 \%$.

Average economic value per unit area did not follow the same rank order because it was unrelated to area of ESPU coverage. The highest value was estimated for broadleaf forest on slopes of $>25^{\circ}$ with high rainfall intensity and red soil. The ecological complexes providing the highest soil conservation service value per hectare are listed in Table 7. The differences in the total and average values of soil conservation service derived from ESPUs are also displayed in Fig. 5. Based on these results, we can identify the dominant contributors and their magnitudes. Clear recognition of the heterogeneity of ecosystem services and their main contributors aids in policy making for ecological compensation.

\section{Suggestions for ecological compensation policy}

Watershed eco-compensation mechanisms and policy have become hot topics in society. However, the absence of economic policies related to watershed eco-compensation often results in the unequal distribution of ecological and

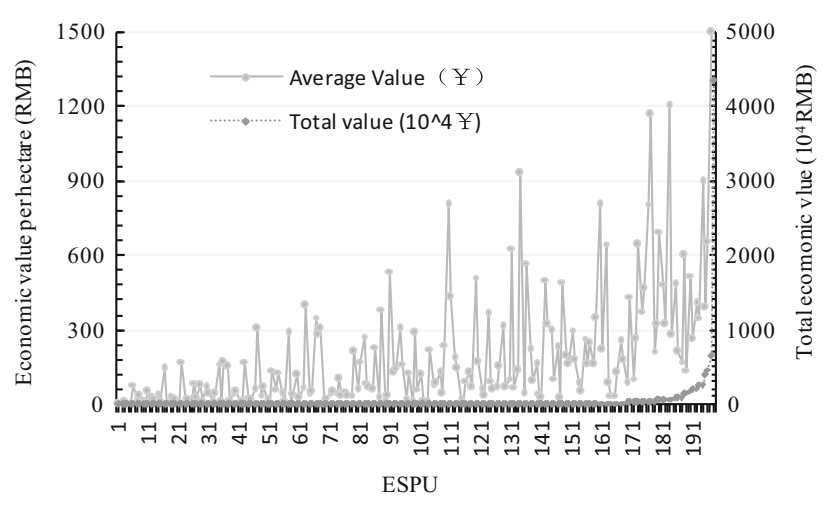

Fig. 5 Soil conservation service value of each ESPU 
Table 6 Information on the precipitation, vegetation, soil, and topography of 11 ESPUs

\begin{tabular}{|c|c|c|c|c|}
\hline Total economic value $\left(10^{6} ¥\right)$ & Rainfall intensity & Soil type & Slope & Forest type \\
\hline 6.58 & High & Red soil & $>25^{\circ}$ & Broadleaf forest \\
\hline 4.66 & High & Red soil & $>25^{\circ}$ & Bamboo forest \\
\hline 3.58 & Middle & Red soil & $>25^{\circ}$ & Bamboo forest \\
\hline 2.65 & Middle & Red soil & $>25^{\circ}$ & Broadleaf forest \\
\hline 2.64 & High & Red soil & Between $15^{\circ}$ and $25^{\circ}$ & Bamboo forest \\
\hline 2.10 & High & Yellow soil & $>25^{\circ}$ & Broadleaf forest \\
\hline 1.92 & Low & Red soil & $>25^{\circ}$ & Bamboo forest \\
\hline 1.90 & High & Red soil & $>25^{\circ}$ & Bamboo forest \\
\hline 1.56 & Low & Red soil & Between $15^{\circ}$ and $25^{\circ}$ & Bamboo forest \\
\hline 1.47 & Low & Red soil & $>25^{\circ}$ & Broadleaf forest \\
\hline 0.94 & Low & Red soil & Between $15^{\circ}$ and $25^{\circ}$ & Coniferous forest \\
\hline
\end{tabular}

These 11 ESPUs contribute $70 \%$ of total economic value

Table 7 Information on the precipitation, vegetation, soil, and topography of nine ESPUs

\begin{tabular}{lllll}
\hline Economic value per hectare $(¥ / \mathrm{ha})$ & Rainfall intensity & Soil type & Slope & Forest type \\
\hline 1498 & High & Red soil & $>25^{\circ}$ & Broadleaf forest \\
1198 & High & Red soil & $>25^{\circ}$ & Broadleaf forest \\
1165 & High & Red soil & $>25^{\circ}$ & Mixed forest \\
932 & High & Red soil & $>25^{\circ}$ & Mixed forest \\
899 & Middle & Red soil & $>25^{\circ}$ & Broadleaf forest \\
809 & High & Red soil & Between $15^{\circ}$ and $25^{\circ}$ & Broadleaf forest \\
805 & High & Red soil & $>25^{\circ}$ & Coniferous forest \\
804 & Middle & Red soil & $>25^{\circ}$ & Shrub forest \\
699 & Middle & Red soil & $>25^{\circ}$ & Mixed forest \\
\hline
\end{tabular}

These nine ESPUs provided the highest soil conservation service value per hectare

Table 8 Economic benefits of per hectare ecological forests and their rates to current standard

\begin{tabular}{llc}
\hline Ecological forest type & Economic value (RMB/ha) & Rates to current standard (\%) \\
\hline Conifer forest & 197.61 & 88 \\
Broadleaf forest & 655.08 & 291 \\
Mixed forest & 411.18 & 183 \\
Shrub forest & 429.74 & 191 \\
Average & 436.27 & 194 \\
\hline
\end{tabular}

economic benefits among protectors and beneficiaries. Communities in the upper reaches of most rivers in China have poor economies and fragile ecosystems, and the people living in these regions require alleviation from poverty. Thus, a balance between economic development and environmental protection should exist in such areas. Effective and acceptable institutional arrangements could encourage upstream water users (small-scale farmers) to reduce erosion from their farms to create benefits for downstream water users such as hydroelectric producers
(Guo et al. 2000; Pimentel et al. 1995). Thus, establishing a watershed eco-compensation mechanism is helpful in dealing with the ecological and economic relationships between upstream and downstream communities.

Anji County is located in the upper reaches of Taihu Lake and requires high expenditure for the protection and maintenance of its abundant forest resources, which provide essential eco-services, such as soil conservation and nutrient control for the overall watershed. However, the current ecological compensation standard for non- 
commercial forest is $225 \mathrm{RMB} / \mathrm{ha}$, which corresponds to half of the economic benefit of forest in soil conservation. Notably, the evaluation method based on eco-service provision unit clearly reveals the dominant contributors to and magnitudes of soil conservation service. Moreover, this method provides the baseline for differentiated ecological compensation standards. From the perspective of soil conservation benefit, broadleaf forest in Anji County should be compensated at thrice the current standard of 225 $\mathrm{RMB} / \mathrm{ha}$, whereas the mixed and shrub forests should be compensated at twice this standard. Conifer forest only requires 0.88 times of the current standard because its actual eco-service may be restricted at low erosion risk. Table 8 indicates the economic benefits of per hectare ecological forests and their rates relative to the current standard of $225 \mathrm{RMB} / \mathrm{ha}$. In addition to soil and nutrient conservation discussed here there are other forest eco-service benefits that should be considered such as recreation and biodiversity conservation. As a result, the monetary value derived from this study is likely to be a lower-bound estimate of the ecological benefits of Anji County forests.

\section{Conclusion}

This study quantified the soil conservation effects of forests in Anji County and converted these effects into monetary terms by using an eco-service unit evaluation method. The forests of Anji County were estimated to reduce soil erosion by $4.08 \times 10^{5}$ tons year $^{-1}$ or 2.86 tons $^{-1}$ year $^{-1}$ by avoiding on-site nutrient loss. From an economic perspective, we estimated the forests of Anji County could provide a benefit of 43.37 million RMB year ${ }^{-1}$ as a result of soil conservation service and a per unit ecological forest contribution of $436 \mathrm{RMB} \mathrm{ha}^{-1}$ year $^{-1}$, which is twice the current standard of ecological compensation. The ecological complexes with higher rainfall intensity, broadleaf forest, red soil, and slope gradients $>25^{\circ}$ had the highest contributions to soil conservation benefits.

In addition, the eco-service provision unit method in this study attempted to combine erosion risk and soil conservation capacity, as well as to reconcile the scientific requirement of rigorous analysis with a political analysis to provide guidelines to arrive at a decision. Nevertheless, even with this correction for soil erosion risk, only a rough estimated can be made because of the lack of actual experiments on soil erosion and nutrient content. Although extensive efforts have been exerted to determine the effects of forest on soil erosion and nutrient control in Anji County, some weaknesses remain because of the limitations on the precision of the economic models and the biological, physical, and ecological process models available. For instance, whether the soil nutrients and their benefits can simply be added to the total effect of forest soil protection as a whole remains unclear. Some approaches are alternatives for each other. Another issue is private versus public costs and benefits: how do the goals of private land users differ from the public good, how can this difference help us to predict land-user behavior, and what incentives would be appropriate to make land-users behave in such a way as to maximize the public good? Therefore, further research should be conducted. Nevertheless, this study contributes to clear identification of the main contributors to ecosystem services and their magnitudes, and can benefit decision making for ecological compensation policy.

Acknowledgments This work was supported by the National Natural Science Foundation (No. 31200531), National Science and Technology Support Program (No. 2012BAC01B08), and the National Environmental Protection Public Welfare Industry Targeted Research (No. 201209027).

\section{References}

Antic L, Jablanovic V (2000) Criteria for evaluating transfer pricing methods. Econ Org 1(8):61-70

Bu ZH, Yang LZ, Bu YH, Wu JY (2002) Soil erodibility $(K)$ value and its application in Taihu Lake catchment. Acta Pedol Sin 39 (3):296-300 (in Chinese)

Cao H, Yang H, Zhao QG (2002) Soil erosion and nutrients loss on the typical slope in hilly region of Taihu Basin. J Lake Sci 14 (3):242-246 (in Chinese)

Chen L, Xie GD, Pei S, Zhang CS, Fan N, Zhang CX, Li SM (2012) Ecosystem's soil conservation function and its spatial distribution in Lancang River Basin, Southwest China. Chin J Appl Ecol 23(8):2249-2256

Cheng HG, Hao FH, Ren XY, Yang ST, Xiong W, Lei SP (2006) The study of the rate loss of nitrogenous non-point source pollution loads in different precipitation levels. Acta Sci Circumst 26 (3):392-397 (in Chinese)

Dong DY, Zhang B, Zhang CQ, Yang YG, Pan CX, Wang B (2011) Assessment on soil nutrients loss of forestland in Anji County of the Taihu Basin. Resour Sci 33(8):1608-1612 (in Chinese)

Feng XL, Zhang HJ, Wang LX (1998) Quantitative evaluation of effects of water conservation forest on conserving soil and water in the Upper stream of Miyun Reservoir. J Beijing For Univ 20 (6):71-77 (in Chinese)

Fu SH, Liu BY (2002) Evolution of the soil erosion model. Adv Earth Sci 17(1):78-84 (in Chinese)

Gassman PW, Osei E, Saleh A, Rodecap J, Norvell S, Williams J (2006) Alternative practices for sediment and nutrient loss control on livestock farms in northeast Iowa. Agric Ecosyst Environ 117:135-144

Grant J, Laffan M, Hill R, Neilsen W (1995) Forest soils of Tasmania. Forestry Tasmania, Hobart, pp 12-15

Guo ZW, Gan YL (2003) Some scientific questions for ecosystem services. Biodivers Sci 11(1):63-69 (in Chinese)

Guo ZW, Xiao XM, Li DM (2000) An assessment of ecosystem services: water flow and hydroelectric power production. Ecol Appl 10:925-936

Guo ZW, Xiao X, Gan YL, Zheng YJ (2001) Ecosystem functions, services and their values-a case study in Xingshan county of China. Ecol Econ 38:141-154 
Guto SN, Pypers P, Vanlauwe B, de Ridder N, Giller KE (2011) Tillage and vegetative barrier effects on soil conservation and short-term economic benefits in the Central Kenya highlands. Field Crops Res 122:85-94

Hansen L, Ribaudo M (2008) Economic measures of soil conservation benefits: regional values for policy assessment. TB-1992.U. S. Dept. of Agriculture, Econ Res Serv pp 1-22

He X, Li Z, Hao M, Tang K, Zheng F (2003) Down-scale analysis for water scarcity in response to soil-water conservation on Loess Plateau of China. Agric Ecosyst Environ 94(3):355-361

Jiang WW, Zhou GM, Yu SQ, Qian XB, Sheng, WM (2004) Research on nutrient status of soils under main forest types in Anji mountainous region. J Soil Water Conserv 18(4):73-100 (in Chinese)

Kong WJ, Zhou BZ, Fu MY, Li ZC, Xie JZ, Wu M (2009) Effects of different land-use on characteristics of soil and water conservation. J Nanjing For Univ (Nat Sci Edn) 33(4):57-61 (in Chinese)

Kuhlman T, Reinhard S, Gaaff, A (2010) Estimating the costs and benefits of soil conservation in Europe. Land Use Policy 27:22-32

Laffan MD, McIntosh PD, Neilsen W (2003) Forest soils derived from granite in northern Tasmania: an overview of properties, distribution and management requirements. Tasforests 14:1-14

Li HP, Liu XM, Huang WY (2004a) The non-point output of different landuse types in Zhexi Hydraulic region of Taihu Basin. Acta Geogr Sin 59(3):401-408 (in Chinese)

Li HP, Liu XM, Liu XM, Yang GS (2004b) Nutrient pollutant load analysis of Xitiaoxi Watershed in Taihu region. J Lake Sci 16 ((Suppl.)):89-98 (in Chinese)

Li ZF, Yang GS, Li HP (2006) Effects of land use on nitrogen export in Xitiaoxi watershed. Chin J Environ Sci 27(3):498-502 (in Chinese)

Li LL, Huang GB, Zhang RZ, Bellotti B, Li GD, Chan KY (2011) Benefits of conservation agriculture on soil and water conservation and its progress in China. Agric Sci China 10(6):850-859 (in Chinese)

Liu N, Wang KL, Zhang W, Zhang XN (2011) Progress on the study of soil erosion, evaluation and validation. Chin Agric Sci Bull 27 (18):1-6 (in Chinese)

Luck GW, Daily GC, Ehrlich PR (2003) Population diversity and ecosystem services. Trends Ecol Evol 18:331-336

McIntosh P, Laffan M (2005) Soil erodibility and erosion hazard: extending these cornerstone soil conservation concepts to headwater streams in the forestry estate in Tasmania. For Ecol Manage 220:128-139

Morgan RPC (1995) Soil erosion and conservation. Longman, London

Page T, Haygarth PM, Beven KJ, Joynes A, Butler T, Keeler C, Freer J, Owens PN, Wood GA (2005) Spatial variability of soil phosphorus in relation to the topographic index and critical source areas: sampling for assessing risk to water quality. J Environ Qual 34:2263-2277

Pimentel D, Harvey C, Resosudarmo P, Sinclair K, Kurz D, McNair M, Crist S, Shpritz L, Fitton L, Saffouri R, Blair R (1995) Environmental and economic costs of soil erosion and conservation benefits. Science 267(5201):1117-1123

Qin YH, Kang MY (2007) A review of ecological compensation and its improvement measures. J Nat Resour 22(4):557-567 (in Chinese)

Rejani R, Yadukumar N (2010) Soil and water conservation techniques in cashew grown along steep hill slopes. Sci Hortic A $126: 371-378$
Renard KG, Freimund JR (1994) Using monthly precipitation data to estimate the R-factor in the revised USLE. J Hydrol 157:287306

Renard KG, Foster GR, Weesies GA, McCool DK, Yoder DC (1997) Predicting Soil Erosion By Water: A Guide to Conservation Planning with the Revised Universal Soil Loss Equation (RUSLE)_USDA Agricultural Handbook 703. U.S Department of Agriculture, Washington DC

Seckler D (1987) Economic costs and benefits of degradation and its repair. Land Degradation and Society Methuen and Co. Ltd., London

State Forestry Administration of China (2008) Specifications for assessment of forest ecosystem services in China. Standards Press of China, Beijing (in Chinese)

Tack Force on Eco-compensation Mechanisms and Policies (2008) Eco-compensation mechanisms and policies in China. Science Press, Beijing

Wang JL, Pu LJ, Jin PH, Wang YF, Pan S, Zhou F (2003) Soil erosion using ${ }^{137} \mathrm{Cs}$ method in upper reaches of Taihu Lake Basin: a case study of Xitiaoxi River Basin in Anji County Zhejiang Province. J Nanjing Univ (Nat Sci) 39(6):788-796 (in Chinese)

Wang ZH, Cai LL, Guan QW, Cai X (2010) Evaluation of forest ecosystem services in Chun'an County. J Zhejiang For Coll 27 (5):757-761 (in Chinese)

Wischmeier WH, Smith DD (1978) Predicting rainfall erosion losses. Agricultural Handbook 537. USDA, Washington, DC

Xie HB, Yu XG, Zhang YL (2001) Preliminary study on the coincident relationship between water environment and human activity in Taihu Lake Basin. Resour Environ Yangtze Basin 10 (5):393-400 (in Chinese)

Yu Z, Wang L (1999) Benefits of water conservation forest. China Forestry Press, Beijing (in Chinese)

Yu XX, Yang GS, Ou WX (2003) Impacts of non-point source pollution on the water environment of Xitiaoxi watershed, upper Taihu Basin. J Lake Sci 15(1):49-55 (in Chinese)

Zeng HA, Wu JL, Lin L (2008) Using 137Cs tracer technique to investigate soil erosion distribution and total erosion amount in Taihu Lake catchment. Mar Geol Quat Geol 28(2):79-85 (in Chinese)

Zhang MK, Han CC (2000) On antierodibility of hilly soils in Zhejiang Province. Acta Agric Zhejiangensis 12(1):25-30 (in Chinese)

Zhang B, Li WH, Xie GD, Xiao Y (2009) Comprehensive assessment of soil conservation capacity of forest ecosystems in Beijing. Res Soil Water Conserv 16(1):240-244 (in Chinese)

Zhang B, Li WH, Xie GD (2010) Ecosystem services research in China: progress and perspective. Ecol Econ 69:1389-1395

Zhang CQ, Zhang B, Yang YG, Wang B (2011) Research on soil nutrients of forest nearby Xitiaoxi River in the upper reaches of Taihu Lake Basin. J Soil Water Conserv 25(5):53-58 (in Chinese)

Zhao JF, Huang GB, Xin P, Xie KZ, Xu AX (2007) Conservation tillage effects on run-off and soil erosion. Bull Soil Water Conserv 27:16-19 (in Chinese)

Zhou BZ, Fu MY, Xie JZ, Yang XS, Li ZC (2005) Ecological function of bamboo forest: research and Application. J For Res 16(2):143-147

Zobeck TM, Schillinger WF, Schillinger WF (2010) Soil and water conservation advances in the United States. SSSA Special Publication \# 60, Madison, p 301 